\title{
The Examination of Kick-Box Athletes' Freedom Perceived in Time and Thrill Seeking Levels
}

\section{Kick Boks Sporcularının Heyecan Arayışı ve Serbest Zamanda Algılanan Özgürlük Düzeylerinin Incelenmesi}

Hakan Bilgen ${ }^{1}$

Kütahya Dumlupınar University

\section{Oğuzhan Yüksel}

Kütahya Dumlupınar University

Received: August 28, 2021

Online Published: September 30, 2021

DOI: $10.30655 /$ besad.2021.37 https://orcid.org/oooo-0002-9504-6321

https://orcid.org/0000-0002-4172-8298

Accepted: September 19, 2021

https://doi.org/10.30655/besad.2021.37

\section{Öz}

Bu araştırmanın amacı: Kick boks sporu ile ilgilenen bireylerin serbest zamanda algıladıkları özgürlük düzeyleri ve heyecan arayışı arasındaki ilişkiyi ortaya çıkarmaktır. Araştırmaya Türkiye sınırları içerisinde yaşayan ve kick boks branşında aktif olan sporculardan uygun örnekleme yöntemi ile belirlenmiştir. Bu araştırmada 355 erkek 238 kadın olmak üzere toplamda 593 katıımcı yer almıştır. Katılımcılardan kişisel bilgi formu, serbest zamanda algılanan özgürlük seviyelerini ölçmek için Witt ve Ellis tarafından (1985) geliştirilen "Serbest Zamanda Algılanan Özgürlük Ölçeği-SZAÖ" ve Hoyle ve arkadaşlarının (2002) geliştirdiği heyecan arayışı ölçeği kullanılmıştır. Veri analizinden önce normallik testi uygulanmış ve verilerin normal dağılım sağladığı belirlenmiştir. Veri analizinde tek yönlü ANOVA ve t-testi kullanılmıştır. Anlamlı farkın kontrolü için Tukey testi uygulanmıştır. Bulgulara göre serbest zaman algısının alt boyutlarından bilgi ve beceri alt boyutunda erkeklerini bilgi ve beceri değerlerinin kadın katıımcılara göre istatistiksel açıdan anlamlı olduğu tespit edilmiştir. Heyecan arayışı değerleri incelendiğinde ise kadın katılımcıların ortalama değerlerinin erkeklere oranla daha fazla olduğu tespit edilmiştir. Medeni durum değişkenine göre heyecan arayışı ölçeğinde bekâr katıımcıların evli katıımcılara göre daha yüksek bir ortalamaya sahip oldukları tespit edilmiştir.

Anahtar Kelimeler: Rekreasyon, savaş sanatı, boş zaman etkinlikleri, coşku

\footnotetext{
${ }^{1}$ Corresponding Author: Hakan Bilgen hakanbilgen81@hotmail.com

Faculty of Sport Sciences, Kütahya Dumlupınar Üniversitesi, Kütahya, Turkey.
} 


\section{Abstract}

The purpose of this study was to examine the relationship between Kick-Box athletes' freedom perceived in time and thrill seeking levels. Appropriate sampling method was used for sample selection. Sample of the study was active kick-box athletes who live in Turkey. There were 355 male and 238 female, totally 593 participants voluntarily accepted to attend this study. Data were collected from demographic information form, the "Leisure Perceived Freedom Scale in Leisure-Time" developed by Witt and Ellis (1985) and "Thrill Seeking Scale" developed by Hoyle et al. (2002). In statistical analysis, one way ANOVA, t-test and follow-up TUKEY test were used. Before the statistical analysis, a normality test was checked and it was found that data were distributed normally. Results showed that males' freedom perceived in time levels were significantly higher than those in females. Females' thrill seeking level was significantly higher than males' thrill seeking level. In the marital status variable, married participants' thrill seeking level was higher than those in single participants.

Keywords: Recreation, martial art, free time activities, enthusiasm

\section{Giriş}

Günümüz dünyasının beraberinde getirdiği hareketsiz yaşam, spora olan ilginin her geçen gün artmasına neden olmuştur. İlginin artmasıyla beraber sporda kendini geliştirmiş ve yeni spor branşları doğmuştur. Bu doğan branşlardan biri de kick boks sporudur. Boks branşında yer alan yumruk kombinasyonları hem de tekmelerin aktif olarak kullanıldığı bir spor disiplinidir. 1960 ve 1970 yıllarda Japonlar ve Amerikalılar tarafından gelişimi sağlanmıştır (Cynarski \& Zieminski, 2010). kick boks bireylerin rekreasyon amaçlı olarak kendilerine ayırdıkları serbest zaman diliminde oldukça rağbet görmektedir.

Rekreasyon ve serbest zaman kavramı insanlık tarihi kadar köklü kavramlar olmasına rağmen terim anlamı ve kuramlarla birlikte değerlendirilmeye başlanması çok sonradan olmuştur. Bundan dolayı gelişmiş ülkelerde mevcut rekreatif faaliyetleri çeşitlilik bakımından sınır tanımazken gelişmekte olan ülkeler ve gelişmemiş ülkelerde bu çeşitliktik söz konusu olmamakla beraber rekreatif faaliyetler aksine sınırlı kalmaktadır. Bu bağlamda serbest zamanımızı değerlendirme noktasında birden fazla faktör devreye girmektedir. Bu faktörlerin başında gelen gelenek ve görenekler rekreatif faaliyetlerin belirlenmesi ve serbest zamanın değerlendirilmesi noktasında etkin olmaktadır (Yumuk, 2019; Godbey, vd., 2005). George ve Santana'ya (2008) göre bazı hususlarda, kültürümüz ve serbest zaman davranışlarımızın kökeni geçmişe dayanmaktadır. Bu davranışlar, geçmişten bu yana insanların yapmış olduğu etkinlikler ve yüzyıllardan beri aktarılan gelenek ve göreneklerin tarihi üzerine kurulmuştur. Bu bağlamda günümüzde rekreatif etkinlikleri ve serbest zaman sebep-sonuç ilişkisi içerisinde karşımıza çıkmaktadır. Zowisło'ya (2010) göre, "çarpıcı ve anlamlı görünen şey şu ki; insana dair her şey aslında serbest zamandan kaynaklanmaktadır". Yani insanlar rekreasyon ve serbest zamanı kendilerine bir gaye olarak belirlenebilecek iken aynı zamanda bu gayenin gerçekleşmesi sonucunda elde ettikleri ürünlerde olabilmektedir.

Passmore ve Frennch (2001) ve Atchley (1971) serbest zaman faaliyetlerini bir son olarak betimlemiş ve plansız, mecburi olmadıklarından bahsetmiştir. Böylece serbest zaman, özünde kendini geliştirmeye adanmış faaliyet olarak karşımıza çıkmaktadır. Günümüz şartları düşünüldüğünde rekreasyon ve serbest zaman faaliyetleri birer ihtiyaç haline gelmiştir. Günlük sorumluluklarını yerine getiren ve bu sorumlulukların baskısı altında hırpalanan insan, rekreatif faaliyet ve serbest zamanın önem kazanmasına neden olmaktadır.

Serbest zaman ve rekreasyon faaliyetlerinin önem kazanması insanların bu alanda kendilerini ifade edebilecek ve fiziksel uygunluklarına uyan spor dallarına yönelmelerine sebep olmaktadır (Ragheb \& Tate, 1993). Temelde rekreasyon eğlence, rahatlama ve kişisel gelişim içindir; özellikle özsaygı, kimlik gelişimi ve stres yönetimi açısından bireylerin ihtiyaçlarına cevap veren bir unsur olduğundan dolayı 
etkinliklerin çoğunluğu gönüllülük esasına dayanmaktadır (Atchley, 1970; Kraus, 1998; Mieczkowski, 1990). Dolayısıyla serbest zamanı değerlendirme ve rekreatif faaliyetlere katılma bireylerin ilgi alanlarına göre farklılık göstermektedir. Bireylerin ilgi alanlarını belirleyen temel unsurların başında monoton bir hayattan çıkıp haz verici etkinlikler yapma isteğidir. Bu isteğe cevap veren yegâne sporlardan biri de kick boks sporu olduğu için bireylerin farklı tecrübeler, hazlar ve heyecanlar noktasında intiyaçlarına cevap vermektedir.

Bu araştırmanın amacı, kick boks sporu ile ilgilenen bireylerin serbest zamanda algıladıkları özgürlük düzeyleri ve heyecan arayışı arasındaki ilişkiyi ortaya çıkarmaktır. Bu bağlamda kick boks branşıyla ilgilenen sporcuların serbest zamanda algılanan özgürlük ve heyecan arayışı düzeylerinin incelenmesi literatüre önemli katkılar sağlayacağı umulmaktadır.

\section{Yöntem}

Bu çalışmada tarama modeli kullanılmıştır. Tarama modelleri geçmişte ya da halen var olan bir olayı var olduğu haliyle betimlemeyi hedefleyen çalışma yaklaşımı olarak tanımlanmaktadır (Karasar, 2012).

\section{Evren ve Örneklem}

Bu çalışmanın evreninin Türkiye'de kick boks sporu ile ilgilenen bireyler oluşturmaktadır. Örneklem grubunu ise kick boks sporuna düzenli bir şekilde katılan 593 sporcu oluşturmaktadır. Kütahya Dumlupınar Üniversitesi etik kurulu çalışmayı onaylamıştır (Etik Kurul No: E.16668). Etik onayı alındıktan sonraki süreçte araştırmanın veri toplama aşamasına geçilmiştir.

\section{Veri Toplama Araçları}

Araştırmanın örneklem grubunu oluşturan Türkiye Kick Boks Federasyonu'nun 2020-2021 yılı içerisinde düzenlediği yarışmalarda yer alan katılımcılara ulaşılması amacıyla federasyondan gerekli izinler alınarak veri tabanından e-posta adreslerine ulaşıımıştır. Google Forms ile katıımcılara ulaştırılan ölçekler için bir aylık bir süre tanınmıştır. Araştırmanın hedefine yönelik hazırlanan kişisel bilgi formunda katıımcıların, medeni durumu, cinsiyeti, yaşadığı yer, spor yaşı, gelir düzeyi, eğitim düzeyi gibi demografik bilgiler yer almaktadır. Katıımcıların serbest zamanda algılanan özgürlük düzeylerini belirlemek için Witt ve Ellis tarafından (1985) geliştirilen "Serbest Zaman Teşhis Bataryasının" bir bölümü olan ve 25 maddeden oluşan "Serbest Zamanda Algılanan Özgürlük Ölçeği-SZAÖ" kullanılmıştır. Serbest Zamanda Algılanan Özgürlük Ölçeğinin Türkçe 'ye uyarlanmasını Yerlisu Lapa ve Ayar (2011) gerçekleştirmiştir. Türkçe 'ye uyarlanan ölçek, iki faktörlü ve 17 maddeden oluşmaktadır. Heyecan arayışı ölçeği, Hoyle ve arkadaşları (2002) tarafından geliştirilmiş ve Turan ve Çelik tarafından (2016) Türk literatürüne kazandırılmıştır. Ölçek 8 madde ve tek boyuttan oluşmaktadır.

\section{Veri Analizi}

Google Forms üzerinden anketleri değerlendiren katıımcıların sonuçları Microsoft Excel programına aktarıldıktan sonra ilgili veriler kontrol edilip gerekli analizlerin yapılması için SPSS 23.0 istatistik programına aktarılmıştır. Verilere uygulanan normallik testi için Kurtosis ve Skewness değerleri kontrol edilmiş ve -3 ve +3 değerleri arasında olması beklenmektedir (Jondeau \& Rockinger, 2008). Normal dağııım sağlandığı için parametrik testlerden Bağımsız örneklemler için Tek yönlü varyans analizi ve T-testi uygulanmıştır. Takip testi olarak da TUKEY tercih edilmiştir. 


\section{Bulgular}

Tablo 1'de çalışmaya katılan bireylerin demografik bilgilerine ilişkin veriler bulunmaktadır. Katılımcıların \%34.40'ı 16 yaş ve altında, \% 24.50'si 17 ile 20 yaş arasında, \%6.70"i 21 ile 24 yaş arasında, \%21.80'i 29 yaş üstüdür. Katıımcıların \%15.50'si evli, \%82.50'si bekardır. Ayrıca \%3.40'ı köyde, \%13.80'i ilçede, \%62,10'u büyükşehir merkezinde ikamet etmektedir.

Tablo 1. Katılımcıların demografik özelliklerine ait frekans dağılımı.

\begin{tabular}{cccc}
\hline \multirow{2}{*}{ Cinsiyet } & & $\mathbf{n}$ & $\%$ \\
& Erkek & 355 & 59.90 \\
& Kadın & 238 & 40.10 \\
\hline \multirow{2}{*}{ Medeni Hal } & Evli & 104 & 17.50 \\
& Bekâr & 489 & 82.50 \\
\hline \multirow{2}{*}{ Yaş } & 16 yaş ve altı & 204 & 34.40 \\
& $17-20$ & 145 & 24.50 \\
& $21-24$ & 75 & 12.60 \\
& $25-28$ & 40 & 6.70 \\
& 29 ve üstü & 129 & 21.80 \\
\hline \multirow{3}{*}{ Yaşanılan yer } & Köy & 20 & 3.40 \\
& i̇lçe & 82 & 13.80 \\
& ill & 123 & 20.70 \\
& Büyükşehir & 368 & 62.10 \\
\hline
\end{tabular}

Tablo 2'de serbest zaman algısının bilgi ve beceri alt boyutunun ortalama değerleri incelendiğinde erkeklerini bilgi ve beceri değerlerinin kadın katıımcılara göre daha fazla olduğu tespit edilmiştir $(t(591)=2.66, p<.05)$. Aynı ölçeğin diğer alt boyutu olan Eğlence ve Heyecan alt boyutunda ise istatistiksel açıdan anlamlı bir fark bulunamamıştır $(t(591)=1.08, p>05)$. Diğer bir ölçek olan heyecan arayışı değerleri incelendiğinde ise kadın katıımcıların ortalama değerlerinin erkeklere oranla daha fazla olduğu tespit edilmiş ve bu iki ortalama değer arasındaki fark istatistiksel yönden de önemli bulunmuştur (t(591)= -2.44 . $p<.05)$.

Tablo 2. Cinsiyet değişkenine göre serbest zaman algısı ve heyecan arayışı t-testi sonuçları.

\begin{tabular}{|c|c|c|c|c|c|c|c|}
\hline Değişken & & Cinsiyet & $\mathbf{N}$ & Ortalama & SS & $\mathbf{t}$ & $p$ \\
\hline \multirow{2}{*}{$\begin{array}{l}\text { Beceri } \\
\text { ve Bilgi }\end{array}$} & Erkek & & 355 & 37.37 & 5.30 & \multirow{2}{*}{2.66} & \multirow{2}{*}{$0.01^{* *}$} \\
\hline & Kadın & & 238 & 36.20 & 5.18 & & \\
\hline \multirow{2}{*}{$\begin{array}{l}\text { Eğlence ve } \\
\text { Heyecan }\end{array}$} & Erkek & & 355 & 33.26 & 5.11 & \multirow{2}{*}{1.08} & \multirow{2}{*}{0.28} \\
\hline & Kadın & & 238 & 32.81 & 4.66 & & \\
\hline \multirow{2}{*}{ HA Toplam } & Erkek & & 355 & 24.18 & 7.89 & \multirow{2}{*}{-2.44} & \multirow{2}{*}{$0.02^{* *}$} \\
\hline & Kadın & & 238 & 25.77 & 7.61 & & \\
\hline
\end{tabular}


${ }^{* *} p<.05$

Tablo 3'de medeni durum değişkenine göre serbest zaman algısının Bilgi ve Beceri $\left(t_{(591)}=1.32, p>\right.$.05) ve Heyecan ve Eğlence $\left(\mathrm{t}_{(591)}=1.98, \mathrm{p}>\right.$.05) alt boyutlarında istatistiksel olarak anlamlı fark tespit edilmemiştir. Heyecan arayışı ölçeğinde ise bekâr katıımcıların evli katıımcılara göre daha yüksek bir ortalamaya sahip oldukları tespit edilmiş ve bu farklılıkta istatistiksel yönden anlamlı olarak bulunmuştur $\left(\mathrm{t}_{(591)}=-6.28\right.$, $\mathrm{p}<.05)$.

Tablo 3. Medeni durumuna göre serbest zaman algısı ve heyecan arayışı sonuçları.

\begin{tabular}{lcccccc}
\hline Değişken & Medeni Hal & $\mathbf{N}$ & Ortalama & sS & t & $\boldsymbol{p}$ \\
\hline $\begin{array}{l}\text { Bilgi ve } \\
\text { Beceri }\end{array}$ & Evli & 104 & 37.52 & 5.34 & 1.32 & 0.19 \\
\hline $\begin{array}{l}\text { Heyecan ve } \\
\text { Eğlence }\end{array}$ & Evkâr & 489 & 36.77 & 5.26 & & \\
\hline & Bekâr & 489 & 32.90 & 4.85 & 1.93 & 0.06 \\
HA Toplam & Evli & 104 & 20.59 & 6.52 & -6.28 & $\mathbf{0 . 0 0 * *}$ \\
& Bekâr & 489 & 25.72 & 7.78 & & \\
\hline
\end{tabular}

${ }^{* *} p<.05$

Tablo 4 incelendiğinde yaş faktörüne göre serbest zaman algısı ölçeği alt boyutlarından beceri ve bilgi alt boyutunda gruplar arasında istatistiksel açıdan anlamlı bir fark olduğu tespit edilmiştir $\left(F_{(4.594)}=3.84\right.$. p<.05). Tukey HSD testi sonuçlarına göre 16 yaş ve altı ile 17-20 yaş ve 29 yaş ve üstü grubu katılımcılar arasında fark söz konusudur. Ancak 17-20 yaş grubu ile 29 yaş ve üstü arasında fark yoktur.

Eğlence ve heyecan alt boyutunda da yaş değişkenine göre gruplar arasında istatistiksel yönden anlamlı bir farklılık olduğu tespit edilmiştir $\left(F_{(4.594)}=2.72, p<.05\right)$. Tukey HSD testi sonuçlarına göre 16 yaş ve altı ile 17-20 yaş grupları arasında farklıık söz konusuyken diğer gruplar arasında farklılık tespit edilmemiştir (Tablo 4). Heyecan arayışı ölçeği sonuçları incelendiğinde yaş grupları arasında istatistiksel yönden anlamlı bir farklılı olduğu belirlenmiştir $\left(F_{(4.594)}=10.44, p<.05\right)$. Tukey HSD sonuçlarına göre 29 yaş ve üstü grup ile 25-28 yaş grubu hariç tüm gruplar arasında anlamlı bir farklıık söz konusudur. Aynı şekilde 25-28 yaş grubu ile 21-24 yaş grubu arasında farklıık söz konusuyken diğer gruplarla arasında farklılı yoktur. 16 yaş ve üstü, 17-20 yaş ve 21-24 yaş gruplarının birbirleriyle aralarında farklılık söz konusu değildir (Tablo 4).

Tablo 4. Yaş değişkeni serbest zaman algısı ve heyecan arayışı Anova sonuçları.

\begin{tabular}{lcccccc}
\hline Değişken & Yaş & $\mathbf{n}$ & Ortalama & SS & F & $\boldsymbol{p}$ \\
\hline & 16 yaş ve altı & 204 & $35.78^{\mathrm{b} *}$ & 4.91 & & \\
Bilgi ve Beceri & $17-20$ & 145 & $37.53^{\mathrm{a}}$ & 5.55 & & \\
& $21-24$ & 75 & $37.51^{\mathrm{ab}}$ & 5.11 & 3.84 & $\mathbf{0 . 0 0}^{\text {** }}$ \\
& $25-28$ & 40 & $36.65^{\mathrm{ab}}$ & 6.00 & & \\
& 29 ve üstü & 129 & $37.67^{\mathrm{a}}$ & 5.16 & & \\
\hline
\end{tabular}




\begin{tabular}{lcccccc}
\hline & 16 yaş ve altı & 204 & $32.27^{\mathrm{a}}$ & 4.49 & & \\
Heyecan ve & $17-20$ & 145 & $33.75^{\mathrm{b}}$ & 5.27 & & \\
Eğlence & $21-24$ & 75 & $33.00^{\mathrm{ab}}$ & 5.23 & 2.72 & $\mathbf{0 . 0 3}^{* *}$ \\
& $25-28$ & 40 & $32.78^{\mathrm{ab}}$ & 4.36 & & \\
& 29 ve üstü & 129 & $33.74^{\mathrm{ab}}$ & 5.11 & & \\
\hline & 16 yaş ve altı & 204 & $25.02^{\mathrm{ab}}$ & 8.02 & & \\
HA Toplam & $17-20$ & 145 & $26.25^{\mathrm{ab}}$ & 7.94 & & $\mathbf{0 . 0 \mathbf { 0 } ^ { * * }}$ \\
& $21-24$ & 75 & $27.80^{\mathrm{a}}$ & 7.45 & 10.44 & \\
& $25-28$ & 40 & $23.53^{\mathrm{bc}}$ & 7.18 & & \\
\hline
\end{tabular}

${ }^{* *} p<.05$

Elde edilen veri analizi sonuçları incelendiğinde serbest zaman algısı ölçeğinin bilgi ve beceri alt $\left(F_{(3.592)}=\right.$ 1.56, $\mathrm{p}>$.05) ve heyecan ve eğlence $\left(F_{(3.592)}=.95, p>\right.$.05) alt boyutlarında ikamet değişkenine göre anlamlı farklılık belirlenmemiştir. Heyecan arayışı ölçeği sonuçları değerlendirildiğinde ikamet değişkenine göre gruplar arasında anlamlı bir farklılı olmadığı tespit edilmiştir $\left(F_{(3.592)}=.30, p>.05\right)$.

Tablo 5. İkamet değişkenine göre serbest zaman algısı ve heyecan arayışı sonuçları.

\begin{tabular}{|c|c|c|c|c|c|c|}
\hline Değişken & İkamet & $\mathbf{n}$ & Ortalama & SS & $\mathbf{F}$ & $p$ \\
\hline \multirow{4}{*}{ Bilgi ve Beceri } & Köy & 20 & 36.05 & 6.85 & \multirow{4}{*}{1.56} & \multirow{4}{*}{.20} \\
\hline & İlçe & 82 & 38.02 & 5.58 & & \\
\hline & il & 123 & 36.79 & 4.84 & & \\
\hline & Büyükşehir & 368 & 36.73 & 5.25 & & \\
\hline \multirow{4}{*}{ Heyecan ve Eğlence } & Köy & 20 & 31.85 & 6.74 & \multirow{4}{*}{.96} & \multirow{4}{*}{.41} \\
\hline & İlçe & 82 & 33.73 & 5.20 & & \\
\hline & il & 123 & 33.15 & 4.35 & & \\
\hline & Büyükşehir & 368 & 32.97 & 4.96 & & \\
\hline \multirow{4}{*}{ HA Toplam } & Köy & 20 & 25.00 & 9.58 & \multirow{4}{*}{.30} & \multirow{4}{*}{.82} \\
\hline & İlçe & 82 & 24.87 & 8.13 & & \\
\hline & il & 123 & 24.23 & 7.96 & & \\
\hline & Büyükşehir & 368 & 25.00 & 7.61 & & \\
\hline
\end{tabular}

${ }^{* *} p<.05$ 
Tablo 6'ya göre serbest zaman algısı ölçeğinin bilgi ve beceri $\left(t_{(184,237)}=5.32, p<.05\right)$ ve heyecan ve eğlence $\left(\mathrm{t}_{(591)}=4.91, \mathrm{p}<.05\right)$ alt boyutlarında gruplar arasında istatistiksel açıdan anlamlı bir farklılık olduğu tespit edilmiştir. Buna karşın Heyecan arayışı ölçeği sonuçlarına göre gruplar arasında anlamlı bir farklılık belirlenmemiştir $\left(\mathrm{t}_{(591)}=1.59, \mathrm{p}>\right.$.05).

Tablo 6. Rekreatif amaçlı spor yapma durumuna göre serbest zaman algısı ve heyecan arayışı ölçeği sonuçları.

\begin{tabular}{|c|c|c|c|c|c|c|}
\hline Değişken & $\begin{array}{l}\text { Rekreatif Amaçlı Spor } \\
\text { Yapma Durumu }\end{array}$ & $\mathbf{n}$ & Ortalama & SS & $\mathbf{t}$ & $p$ \\
\hline \multirow{3}{*}{ Bilgi ve Beceri } & Evet & 480 & 37.41 & 5.28 & \multirow{3}{*}{5.32} & \multirow{3}{*}{$0.00^{* *}$} \\
\hline & & & & & & \\
\hline & Hayır & 113 & 34.73 & 4.71 & & \\
\hline \multirow{2}{*}{$\begin{array}{l}\text { Heyecan ve } \\
\text { Eğlence }\end{array}$} & Evet & 480 & 33.55 & 4.87 & \multirow{2}{*}{4.91} & \multirow{2}{*}{$0.00^{* *}$} \\
\hline & Hayır & 113 & 31.06 & 4.74 & & \\
\hline \multirow{3}{*}{ HA Toplam } & Evet & 480 & 25.07 & 7.91 & \multirow{3}{*}{1.59} & \multirow{3}{*}{0.11} \\
\hline & & & & & & \\
\hline & Hayır & 113 & 23.77 & 7.34 & & \\
\hline
\end{tabular}

Tablo 7'e göre serbest zaman algısı ölçeğinin her iki alt boyutu arasında yüksek düzeyde pozitif yönde anlamlı bir ilişki olduğu belirlenmiştir. Bilgi ve beceri alt boyutu ile heyecan arayışı ölçeği arasında anlamlı bir ilişki söz konusudur. Ancak bu ilişki negatif yönde ve kuvveti de zayıftır. Yine aynı şekilde Eğlence ve heyecan alt boyutu ile heyecan arayışı ölçeği arasında da anlamlı bir ilişki söz konusudur ve bu ilişki negatif yöndedir ve kuvvet düzeyini zayıf olduğu tespit edilmiştir.

Tablo 7. Serbest zaman algısı ve heyecan arayışı ölçeği korelasyon tablosu.

\begin{tabular}{lccc}
\hline & Beceri ve Bilgi & $\begin{array}{c}\text { Eğlence ve } \\
\text { Heyecan }\end{array}$ & HA Toplam \\
\hline Beceri ve Bilgi & 1 &, $815^{* *}$ &,$- 113^{* \prime}$ \\
Eğlence ve Heyecan &, $815^{* \prime}$ & 1 &,$- 095^{\circ}$ \\
HA Toplam &,$- 113^{*}$ &,$- 095^{*}$ & 1 \\
\hline
\end{tabular}

${ }^{*} p<0,05$

${ }^{* *} p<0,01$ 


\section{Tartışma}

Bu çalışmada, kick boks sporu ile ilgilenen bireylerinin heyecan arayışı ve serbest zamanda algılanan özgürlük seviyeleri farklı parametrelere göre incelenmiştir. Heyecan arayışı ve serbest zamanda algılanan özgürlük düzeyleri arasındaki ilişkinin farklı demografik özelliklerden etkilendiği anlaşılmıştır. Katıımcıların cinsiyet değişkenlerine göre ele alındığında erkeklerin bilgi ve beceri değerlerinin kadın katılımcılara göre daha yüksek düzeyde olduğu görülmektedir. Heyecan ve eğlence alt boyutunda ise istatistiksel açıdan anlamlı bir fark bulunmadığı belirlenmiştir. Lapa ve Ağyar (2012) yapmış olduğu çalışmada, serbest zamanda algılanan özgürlük puanlarının cinsiyete göre farklı olmadığını ancak kültürel/sanatsal, sportif ve sosyal faaliyetlere aktif yer almaları ayrıca katılınan etkinlik sayısının artmasıyla yükseldiği ifade etmişlerdir. Murathan ve ark. (2019) tarafından yapılan çalışmada kız öğrencilerin erkek öğrencilere göre serbest zaman açısından karar vermede çok daha sosyal ve pozitif olduklarını ifade etmektedirler. Emrah ve Ay (2016) yürüttüğü çalışmada, cinsiyet ve yaşın serbest zamanda algılanan özgürlük düzeyinde önemli bir etken olmadığı belirtmektedirler. Beşikçi (2016) macera rekreasyonunda, heyecan arayışı, serbest zaman motivasyonu ve serbest zaman tatmini arasındaki ilişkiye yönelik çalışmada, pilotların heyecan arama düzeyleri ve serbest zaman motivasyonları ve serbest zaman tatminlerine bağlı olarak yaş, medeni, durum, cinsiyet, gelir seviyesi ve eğitim durumları değişkenlerinde anlamlı farklılıklar bulunmuştur. Kaas ve ark. (2020) yapmış olduğu çalışmada, serbest zaman egzersiz düzeyleri ile algılanan özgürlük puanları arasında pozitif yönde anlamlı bir ilişki bulmuşlardır ( $r=0.234, p<0.05$ ). Erkek katıımcılar, kadınlara oranla daha yüksek seviyede algılanan özgürlük değerine sahip olduğu görülmüştür. Demiral (2018) yapmış olduğu çalışmada, katılımcıların serbest zaman tatmin düzeylerinin tüm alt boyutlarda, yaş, eğitim durumu, cinsiyet, aylık gelir durumuna göre anlamlı olarak değişmediği, medeni durum değişkeninde ise fizyolojik alt boyutunda serbest zaman tatminlerinin anlamlı olarak değiştiğini ifade etmektedir. Diğer bir ölçek olan heyecan arayışı değerleri incelendiğinde ise kadın katıımcıların ortalama değerlerinin erkeklere oranla daha yüksek düzeyde olduğu tespit edilmiştir. Emir (2015) yapmış olduğu araştırmada, kadınların fiziksel aktiviteye katılımı rekreasyonel etkinliklere iştirak etmenin sonucundaki beklentilerinin (heyecan ve eğlence, bilgi ve beceri) karşılanmasında daha etkili olduğu belirtmiştir. Yumuk (2019) yapmış olduğu çalışmada cinsiyet değişkenin heyecan arama üzerinde anlamlı bir fark olduğunu ve heyecan arayışı ölçeğinde elde edilen toplam puanların sonucunda erkek katılımcıların lehine bir sonucun ortaya çıktığı ifade edilmektedir. Katılımcıların medeni hal değişkenlerine göre serbest zaman algısı ve heyecan arayışı sonuçları değerlendirildiğinde serbest zaman algısının ne "Bilgi ve Beceri" üzerine ne de "Heyecan ve Eğlence" alt boyutları üzerine istatistiksel yönden anlamlı kabul edilecek bir etkiye sahip olmadıkları tespit edilmiştir. Buna karşın heyecan arayışı ölçeğinde, bekar katılımcıların evli katıımcılara göre daha yüksek bir ortalamaya sahip olduğu göze çarpmaktadır. Janke ve ark. (2010) yaptıkları çalışmada, bekar bireylerin serbest zamanda algılanan özgürlük düzeylerinin evli yetişkin bireylere kıyasla daha özgür olduğu ifade edilmektedir. Katılımcıların yaş değişkenlerine göre serbest zaman algısı ve heyecan arayışı sonuçları incelendiğinde serbest zaman algısı ölçeği alt boyutlarından "Bilgi ve Beceri" alt boyutunda gruplar arasında istatistiksel yönden anlamlı bir fark olduğu görülmüştür. Tukey HSD testi sonuçlarına göre 16 yaş ve altı ile 17-20 yaş ve 29 yaş ve üstü grubu katılımcılar arasında fark söz konusudur. Ancak 17-20 yaş grubu ile 29 yaş ve üstü arasında fark yoktur. Aynı şekilde diğer hiçbir yaş grubu arasında istatistiki farklıık yoktur. Beceri ve bilgi alt boyutunda olduğu gibi heyecan ve eğlence alt boyutunda da yaş değişkenine göre gruplar arasında istatistiksel yönden anlamlı bir farklılı olduğu bulunmuştur. Tukey HSD testi sonuçlarına göre 16 yaş ve altı ile 17-20 yaş grupları arasında farklıık söz konusuyken diğer gruplar arasında farklııı söz konusu değildir. Heyecan arayışı ölçeği sonuçları incelendiğinde yine diğer ölçeklerde olduğu gibi yaş grupları arasında istatistiksel yönden anlamlı bir farklıık olduğu görülmüştür. Tukey HSD sonuçlarına göre 29 yaş ve üstü grup ile 25-28 yaş grubu hariç tüm gruplar arasında anlamlı bir farklıık söz konusudur. Aynı şekilde 25-28 yaş grubu ile 21-24 yaş grubu arasında 
farklılık söz konusuyken diğer gruplarla arasında farklılık yoktur. 16 yaş ve üstü, 17-20 yaş ve 21-24 yaş gruplarının birbirleriyle aralarında farklıık söz konusu değildir.

\section{Sonuç}

Çalışmanın sonuçları şöyle özetlenebilir: Katılımcıların cinsiyet değişkenine göre serbest zaman algısı ve heyecan arayışı davranışı erkeklerin bilgi ve beceri değerlerinin kadın katılımcılara göre daha yüksek seviyede olduğu bu farklıığın istatiksel açıdan anlamlı olduğu bulunmuştur. Eğlence ve heyecan alt boyutunda ise istatistiksel açıdan anlamlı bir fark bulunmamıştır.

Katıımcıların medeni hal değişkenine göre serbest zaman algısı ve heyecan arayışı serbest zaman algısının "ne Beceri ve Bilgi" üzerine ne de "Eğlence ve Heyecan" alt boyutları üzerine istatistiksel yönden anlamlı kabul edilecek bir etkiye sahip olmadıkları tespit edilmiştir. Buna karşın heyecan arayışı ölçeğinde, bekar katılımcıların evli katıımcılara göre daha yüksek bir ortalamaya sahip oldukları tespit edilmiş ve bu farklıık istatistik açıdan anlamlı olarak bulunmuştur.

Katıımcıların yaş faktörüne göre serbest zaman algısı ve heyecan arayışı serbest zaman algısı ölçeği alt boyutlarından "Beceri ve Bilgi" alt boyutunda gruplar arasında istatistiksel yönden anlamlı bir fark olduğu tespit edilmiştir. 16 yaş ve altı ile 17-20 yaş ve 29 yaş ve üstü grubu katılımcılar arasında fark söz konusudur. Ancak 17-20 yaş grubu ile 29 yaş ve üstü arasında fark yoktur. Aynı şekilde diğer hiçbir yaş grubu arasında istatistiki farklılık yoktur. Beceri ve bilgi alt boyutunda olduğu gibi heyecan ve eğlence alt boyutunda da yaş değişkenine göre gruplar arasında istatistiksel yönden anlamlı bir farklılık olduğu bulunmuştur. 16 yaş ve altı ile 17-20 yaş grupları arasında farklılı söz konusuyken diğer gruplar arasında farklıık söz konusu değildir. Heyecan arayışı ölçeği sonuçları incelendiğinde yine diğer ölçeklerde olduğu gibi yaş grupları arasında istatistiksel açıdan anlamlı bir farklılı olduğu bulunmuştur.

Katılımcıların ikamet değişkenine göre serbest zaman algısı ve heyecan arayışı serbest zaman algısı ölçeğinin "Bilgi ve Beceri" alt boyutunda ikamet değişkenine göre istatistiksel açıdan anlamlı bir farklıık söz konusu değildir. Aynı şekilde ikamet değişkenine göre serbest zaman algısı ölçeğinin heyecan ve eğlence alt boyutu incelendiğinde gruplar arasına istatistiki açıdan önemli bir fark olmadığı tespit edilmiştir. Yine heyecan arayışı ölçeği sonuçları değerlendirildiğinde ikamet değişkenine göre gruplar arasında anlamlı bir farklıık olmadığı bulunmuştur.

Katıımcıların rekreatif amaçlı spor yapma durumu değişkenine göre serbest zaman algısı ve heyecan arayışı serbest zaman algısı ölçeğinin hem "Beceri ve Bilgi" hem de "Eğlence ve Heyecan" alt boyutlarında gruplar arasında istatistiksel yönde anlamlı bir farklılık olduğu bulunmuştur. Buna karşın Heyecan arayışı ölçeği sonuçlarına göre gruplar arasında anlamlı bir farklıık belirlenmemiştir.

Katıımcıların serbest zaman algısı ve heyecan arayışı düzeyleri arasında korelasyona bakıldığında serbest zaman algısı ölçeğinin her iki alt boyutu arasında yüksek seviyede olumlu yönde anlamlı bir ilişki olduğu bulunmuştur. Bilgi ve beceri alt boyutu ile heyecan arayışı ölçeği arasında düşük seviyede negatif yönde bir ilişki söz konusudur. Aynı şekilde Eğlence ve heyecan alt boyutu ile heyecan arayışı ölçeği arasında negatif yönde anlamlı bir ilişki olduğu tespit edilmiştir.

\section{Kaynakça}

Atchley, R. C. (1970). Recreation and Leisure. In understanding American Society: The dynamics of social institutions. Belmont, Calif: Wadsworth. 
Atchley, R. C. (1971). Retirement and leisure participation: Continuity or crisis?. The Gerontologist, 11(1_Part_1), 13-17.

Beşikçi, T. (2016). Macera rekreasyonunda heyecan arayışı, serbest zaman motivasyonu ve serbest zaman tatmini arasındaki ilişkinin incelenmesi: çok haffi hava araçları (çhha) pilot örneği (Yüksek Lisans Tezi). Celal Bayar Üniversitesi, Sosyal Bilimler Enstitüsü, Rekreasyon Anabilim Dalı, Manisa.

Cynarski W.J., Zieminski P. (2010), Holland's primacy in world of K-1 kick-boxing organization, "Ido - Ruch dla Kultury / Movement for Culture", vol. 10, no. 1, pp. 31-35

Demiral, S. (2018). Açık alan rekreasyonuna katılan bireylerin serbest zaman tatmin düzeylerinin incelenmesi: Şavşat-Karagöl örneği. Batman Üniversitesi, Lisansüstü Eğitim Enstitüsü, Beden Eğitimi ve Spor Anabilim Dalı, Batman.

Ellis, G. D., \&Witt, P. A. (1994) Perceived freedom in leisure and satisfaction: exploring the factor structure of the perceived freedom components of the leisure diagnostic battery. Leisure Sciences, 16, 259-270. https://psycnet.apa.org/doi/10.1080/01490409409513236.

Emir, E., (2015). Kadınlarda rekreasyonel etkinliklere katıım: algılanan özgürlük ve mutluluk ilişkisi. 8. Ulusal Spor Bilimleri Öğrenci Kongresi, 14-16 Mayıs, Mersin.

George J MD, B., \& Santana, J. (2008). Kickboks Sporcuları İçin Kondisyon Stratejileri. Strength and Conditioning Journal, 43.

Godbey, G.C., Caldwell, L.L., Floyd, M. ve Payne, L.L. (2005). Contributions leisure studies and recreation and park management research to the active living agenda. American Journal of Preventive Medicine, 28 (2), s.150-158.

Janke, M., Carpenter, G., Payne, L., Stockard, J. (2010). The role of life experiences on perceptions of leisure during adulthood: a longitudinal analysis. Leisure Sciences, 33, 52-69. https://doi.org/10.1080/01490400.2011.533108.

Jondeau, E.,Rockinger, M. (2003). Conditional volatility, skewness, and kurtosis: existence, persistence, and comovements. Journal of Economic Dynamics \& Control, 27, 1699 - 1737.

Kaas, E. T., Lapa, T. Y., Çerez, M. H., \& Çevik, G. (2020). Leisure Activity Participation, Exercise Level and Perceived Freedom in University Students (Akdeniz University Example. 11th International Conference on Business Management \& Information Technology (ICOBMIT). https://ssrn.com/abstract=3643786

Karasar, N. (2012). Bilimsel Araştırma Yöntemi. 24. baskı, Nobel Akademik Yayıncılık Eğitim Danışmanlık Ticaret Ltd. Şti., Ankara.

Millî Eğitim Bakanlığı (2018) Milli Eğitim Istatistikleri Örgün Eğitim.

Kraus R. G. (1998). Recreation and leisure in modern society. Canada: Jones and Bartlett Publishers.

Lapa, T. Y., \& Ağyar, E. (2012). Üniversite Öğrencilerinin Serbest Zaman Katıımlarına Göre Algılanan Özgürlük. Spor Bilimleri Dergisi, 23(1), 24-33.

Li, C.-Y., Lu, S.-Y., Tsai, B.-K., \& Yu, K.-Y. (2015). The impact of extraversion and sensation seeking on tourist role. Social Behavior and Personality: An International Journal, 43(1), 75-84. https://doi.org/10.2224/sbp.2015.43.1.75.

Mieczkowski, Z. (1990). World trends in tourism and recreation. P. Lang.

Murathan, T., Türker, A., \& Murathan, F. (2019). Investigation of university students attitudes toward leisure time activities (Ardahan University sample). Turkish Journal of Sport and Exercise, 21(1), 162-169. 
Passmore, A., \& French, D. (2001). Development and administration of a measure to assess adolescents' participation in leisure activities. Adolescence, 36(141), 67.

Ragheb M. G., Tate R. L. (1993). A behavioural model of leisure participation, Based on leisure attitude, Motivation and satisfaction. Leisure Studies. 12(1): 61- 70. 18.

Serdar, E., \& Ay, S.M. (2016). Üniversite Öğrencilerinin Katıldıkları Serbest Zaman Etkinliklerinden Tatmin Olma ve Algılanan Özgürlük Düzeylerinin İncelenmesi. İstanbul Üniversitesi Spor Bilimleri Dergisi, 6(2), 34-44.

Wu H.C., Liu A, Wang C.H. (2010). Taiwanese University students' perceived freedom and participation in leisure. Annals of Leisure Research, 13(4), 679-700. https://doi.org/10.1080/11745398.2010.9686870.

Yumuk, D. E. (2019). Heyecan arayışı ile yaşam doyumu ve serbest zamanda algılanan özgürlük düzeyi ilişkisi: İmir korku evleri örneği (Yüksek Lisans Tezi). Manisa Celal Bayar Üniversitesi, Sosyal Bilimler Enstitüsü, Rekreasyon Ana Bilim Dalı, Manisa.

Zowisło, M. (2010). Leisure as a Category of Culture, Philosophy and Recreation. Physical Culture and Sport. Studies and Research, 50(1), 66-71. 